\title{
BAB I
}

\section{PENDAHULUAN}

\section{A.Latar Belakang}

Negara Indonesia adalah negara hukum. Sebagai negara hukum, berarti di negara kita hukumlah yang mempunyai arti penting terutama dalam semua segi-segi kehidupan masyarakat. Segala penyelenggaraan yang dilaksanakan oleh negara dengan perantaraan pemerintahnya harus sesuai dan menurut saluran-saluran yang telah ditentukan terlebih dahulu oleh hukum.

Karena negara Indonesia merupakan negara hukum, tiap tindakan penyelenggara negara harus berdasarkan hukum. Peraturan perundang-undangan yang telah diadakan lebih dahulu, merupakan batas kekuasaan penyelenggaraan negara. Undang Undang Dasar yang memuat norma-norma hukum dan peraturan-peraturan hukum harus ditaati, juga oleh pemerintah atau badan-badannya sendiri.

Dalam mempergunakan istilah "Negara Hukum", ternyata terdapat perbedaan penggunaan istilah diantara para ahli ketatanegaraan. Para ahli di Eropa Barat (Kontinental) seperti Immanuel Kant danF.J. Stahlmenggunakan istilah "Rechtsstaat", sedangkan A.V. Diceymenggunakan istilah "Rule Of Law". Kedua istilah tersebut secara formil dapat mempunyai arti yang sama, yaitu negara hukum, akan tetapi secara materiil mempunyai arti yang berbeda yang disebabkan oleh latar belakang sejarah dan pandangan hidup suatu bangsa.

A.V. Diceymengetengahkan tiga arti dari "the rule of law" yaitu pertama, supremasi hukum (supremacy of law); kedua, persamaan di hadapan hukum (equality before the law); ketiga, terjaminnya hak-hak asasi manusia dalam Konstitusi. Adapun untuk "rechtsstaat" 
menurut F.J. Stahlmempunyai unsur-unsur : pertama, pengakuan dan perlindungan terhadap hak asasi manusia; kedua; pemisahan dan pembagian kekuasaan negara (trias politica); ketiga, pemerintah H.Salmon, eksistensi Peradilan Tata Usaha Negara.............Jurnal Sasi Vol. 16 No. 4 Bulan Oktober -Desember 201017berdasarkan undang-undang (wetmatig bestuur); keempat, adanya peradilan administrasi negara (PTUN) (lihat Muhammad Tahir Azhary, 1992 : 66 dan Philipus M. Hadjon, 1987 : 80).

Dalam rule of law menurut sistem Anglosaxon terdapat perbedaan dengan rechsstaat menurut faham Eropa Kontinental. Perbedaan itu antara lain dalam rule of law, tidak terdapat peradilan administrasi negara (PTUN) yang terpisah dari peradilan umum. Lain halnya dalam rechtsstaat terdapat peradilan administrasi negara (PTUN) yang berdiri sendiri terpisah dari peradilan umum. Adapun persamaannya antara lain keduanya (baik rechtsstaat maupun rule of law) mengakui perlindungan HAM, adanya "kedaulatan hukum" atau "supremsi hukum", tidak ada penyalah gunaan kekuasaan atau perbuatan sewenang-wenang oleh Penguasa (absence of arbitrary power).

Melihat kedua sistem tersebut, sebagaimana diketahui secara umum negara Indonesia identik dengan rechtsstaat. Untuk lebih detailnya perlu pula penulis telaah pemikiran-pemikiran ahli hukum Indonesia yang terkenal, yaitu Oemar Seno Adji, Padmo Wahyono, dan Philipus M. Hadjon.

Oemar Seno Adjiberpendapat bahwa Negara Hukum Indonesia memiliki ciri-ciri khas Indonesia. Karena Pancasila harus diangkat sebagai dasar pokok dan sumber hukum, maka Negara Hukum Indonesia dapat pula dinamakan Negara Hukum Pancasila (Muhammad Tahir Azhary, 1992 : 69). Dengan kata lain, Negara Hukum Pancasila ini muncul karena digali oleh 
para proklamator negara dari adat-istiadat asli masyarakat di Indonesia secara keseluruhan yang heterogen dan majemuk berlandaskan asas Bhineka Tunggal Ika.

Menyambung pengertian Negara Hukum Pancasila tersebut, Padmo Wahyonomenelaahnya dengan bertitik pangkal dari asas kekeluargaan yang tercantum dalam UUD 1945 (asas ini masih tetap ada meskipun UUD 1945 telah di amandemen, vide Pasal 33). Menurut Padmo Wahyonodalam asas kekeluargaan makayang diutamakan adalah "rakyat banyak, namun harkat dan martabat manusia tetap dihargai” (Muhammad Tahir Azhary, 1992 : 69-70). Jadi menurut beliau, pemerintah dalam menjalankan roda pemerintahan maka harus memperhatikan aspekKeberadaan pengadilan administrasi negara (PTUN) di berbagainegara modern terutama negara-negara penganut paham Welfare State(Negara Kesejahteraan) merupakan suatu tonggak yang menjadi tumpuan harapan masyarakat atau warga negara untuk mempertahankan hak-haknya yang dirugikan oleh perbuatan hukum publik pejabat administrasi negara karena keputusan atau kebijakan yang dikeluarkannya. kepentingan umum dan hak asasi manusia.

Di Indonesia, pengadilan administrasi negara dikenal dengan pengadilan tata usaha negara sebagaimana diatur dalam UU No.5 Tahun 1986 Jo UU No. 9 Tahun 2004. Berdasarkan Pasal 24 ayat (3) Amandemen ketiga Undang-Undang Dasar 1945 yang disahkan 10 November 2001 Jo pasal 10 ayat (2) UU No. 4 Tahun 2004 Tentang Kekuasaan Kehakiman dikenal 4 lingkungan lembaga peradilan, yaitu: Peradilan Umum, Peradilan Agama, Peradilan Militer, dan Peradilan Tata Usaha Negara. Tiap-tiap lembaga ini mempunyai kewenangan dan fungsi masingmasing, sehingga lembaga-lembaga peradilan ini mempunyai kompetensi absolut yang berbeda satu dengan lainnya. 


\section{BAB II}

\section{PEMBAHASAN}

\section{Peradilan Administrasi Negara (PTUN) dan Perlindungan Hukum bagi Masyarakat di Indonesia}

Tujuan pembentukan dan kedudukan suatu peradilan administrasi negara (PTUN) dalam suatu negara, terkait dengan falsafah negara yang dianutnya. Negara Kesatuan Republik Indonesia merupakan negara hukum berdasarkan Pancasila dan UUD 1945, oleh karenanya hak dan kepentingan perseorangan dijunjung tinggi disamping juga hak masyarakatnya. Kepentingan perseorangan adalah seimbang dengan kepentingan masyarakat atau kepentingan umum. Karena itu, menurut S.F Marbun(1997 : 27) secara filosofis tujuan pembentukan peradilan administrasi negara (PTUN) adalah untuk memberikan perlindungan terhadap hak-hak perseorangan dan hakhak masyarakat, sehingga tercapai keserasian, keseimbangan dan keselarasan antara kepentingan perseorangan dengan kepentingan masyarakat atau kepentingan umum.

Selain itu, menurut Prajudi Atmosudirdjo(1977: 69), tujuan dibentuknya peradilan administrasi negara (PTUN) adalah untuk mengembangkan dan memelihara administrasi negara yang tepat menurut hukum (rechtmatig) atau tepat menurut undang-undang (wetmatig) atau tepat secara fungsional (efektif) atau berfungsi secara efisien. Sedangkan Sjachran Basah(1985 : 25)secara gamblang mengemukakan bahwa tujuan pengadilan administrasi negara (PTUN) ialah memberikan pengayoman hukum dan kepastian hukum, tidak hanya untuk rakyat semata-mata melainkan juga bagi administrasi negara dalam arti menjaga dan memelihara keseimbangan kepentingan masyarakat dengan kepentingan individu. Untuk administasi negara akan terjaga 
ketertiban, ketentraman dan keamanan dalam melaksanakan tugas-tugasnya demi terwujudnya pemerintahan yang kuat bersih dan berwibawa dalam negara hukum berdasarkan Pancasila.

Dengan demikian lembaga pengadilan administrasi negara (PTUN) adalah sebagai salah satu badan peradilan yang melaksanakan kekuasaan kehakiman, merupakan kekuasaan yang merdeka yang berada di bawah Mahkamah Agung dalam rangka menyelenggarakan peradilan guna menegakkan hukum dan keadilan. Penegakan hukum dan keadilan ini merupakan bagian dari perlindungan hukum bagi rakyat atas perbuatan hukum publik oleh pejabat administrasi negara yang melanggar hukum. Berdasarkan hal tersebut, maka peradilan administrasi negara (PTUN) diadakan dalam rangka memberikan perlindungan (berdasarkan keadilan, kebenaran dan ketertiban dan kepastian hukum) kepada rakyat pencari keadilan (justiciabelen) yang merasa dirinya dirugikan akibat suatu perbuatan hukum publik oleh pejabat administrasi negara, melalui pemeriksaan, pemutusan dan penyelesaian sengketa dalam bidang administrasi negara.Dengan demikian, dapat dikatakan bahwa meskipun segala bentuk tindakan pejabat administrasi negara telah diatur dalam norma-norma hukum administrasi negara akan tetapi bila tidak ada lembaga penegak hukum dari hukum administrasi negara itu sendiri, maka norma-norma.

tersebut tidak mempunyai arti apa-apa. Oleh sebab itu eksistensi pengadilan administrasi negara (PTUN) sesuatu yang wajib, dengan maksud selain sebagai sarana kontrol yuridis terhadap pelaksana administrasi negara juga sebagai suatu bentuk atau wadah perlindungan hukum bagi masyarakat karena dari segi kedudukan hukumnya berada pada posisi yang lemah.Berkenaan dengan konsep perlindungan hukum bagi masyarakat di Indonesia, sesungguhnya beranjak dari makna Pancasila yang berarti kekeluargaan atau gotong royong,menurut Philipus M. Hadjon (1993 : 85-89)asas berdasarkan jiwa kekeluargaan ini dapat disebut pula sebagai asas kerukunan. Asas kerukunan tersebut melandasi hubungan antara 
pemerintah dengan rakyat, serta antara organ kekuasaan negara yang satu dengan lainnya yang melahirkan hubungan fungsional proporsional antara kekuasaan-kekuasaan negara.Atas dasar keserasian hubungan berdasarkan asas kerukunan, maka sedapat mungkin penyelesaian sengketa dilakukan melalui cara musyawarah dan peradilan merupakan saranaterakhir. Hal itu karena musyawarah sebagai cerminan perlindungan hukum preventif berupa pemberian kesempatan kepada rakyat untuk mengajukan keberatan atau pendapatnya sebelum pemerintah memberikan keputusan yang definitif. Musyawarah sangat besar artinyaditinjau dari perbuatan pemerintahan yang didasarkan pada kebebasan bertindak karena pemerintah akan terdorong untuk mengambil sikap hati-hati, sehingga sengketa yang kemungkinan dapat terjadi dapat dicegah.Sengketa yang dimaksud adalah berdasarkan Pasal1 butir 4 UU No.5 Tahun 1986 Jo UU No. 9 Tahun 2004, yang menyebutkan bahwa :"Sengketa tata usaha negara (sengketa administrasi negara) adalah sengketa yang timbul dalam bidang tata usaha negara (administrasi negara) antara orang atau badan hukum perdata dengan badan atau pejabat tata usaha negara (pejabat administrasi negara) baik di pusat maupun di daerah, sebagai akibat dikeluarkannya keputusan tata usaha negara (keputusan administrasi negara), termasuk kepegawaian berdasarkan peraturan perundangundangan yang berlaku.

\section{Penegakan Hukum AdministrasiNegara sebagai Upaya membentuk Pemerintahan Yang Bersih (Good Governance)}

Indonesia sebagai penganut paham negara hukum modern, dituntut adanya peranan dan fungsi hukum yang secara stabil dan dinamis mampu mengatur berbagai kepentingan tanpa meninggalkan ide dasarnya yaitu keadilan. Hukum yang demikian juga mengandung tuntutan untuk ditegakkan atau dengan kata lain, perlindungan hukum yang diberikan merupakan suatu 
keharusan dalam penegakan hukum. Maksud penegakan hukum tersebut diatas, penulis sependapat dengan apa yang diutarakan Abdulkadir Muhammad(2001 : 115). Menurutnya, penegakan hukum dapat dirumuskan sebagai usaha melaksanakan hukum sebagaimana mestinya, mengawasi pelaksanaannya agar tidak terjadi pelanggaran, dan jika terjadi pelanggaran maka untuk memulihkannya kembali dengan penegakan hukum. Dengan demikian penegakan hukum dilakukan dengan penindakan hukum, yang menurut penulis dapat diklasifikasikan sebagai berikut :

a.Teguran peringatan supaya menghentikan pelanggaran dan jangan berbuat lagi.

b.Pembebanan kewajiban tertentu (ganti kerugian dan atau denda).

c.Pencabutan hak-hak tertentu (sanksi administrasi ringan, sedang, dan berat seperti : berupa pencopotan jabatan atau pemberhentian dengan tidak hormat).

d.Publikasi kepada masyarakat umum (media cetak dan atau elektronik).

e.Rekomendasi black listsecara politis (kepada lembaga eksekutif, legislatif, dan yudikatif terutama apabila yang bersangkutan akan menjalani fit and proper test).

f.Pengenaan sanksi badan (pidana penjara).

Meskipun penegakan hukumadministrasi negara sebagaimana tersebut diatas dalam prakteknya jarang dipatuhi, menurut hemat penulis permasalahan semua ini bermuara pada moralitas dari pejabat yang bersangkutan dan peraturan perundang-undangan yang tidak secara tegas mengatur pengenai pelaksanaan hukuman/ sanksi dari lembaga pengadilan administrasi negara (PTUN).Permasalahan mengenai moralitas pejabat memang sangat abstrak sehingga sangat sulit dianalisa ketidak patuhan secara hukum pejabat tersebut karena berkenaan dengan kejiwaan (humanistis) dan latar belakang kehidupan pejabat yang bersangkutan. Meskipun demikian, perlu adanya alat kontrol lainnya dalam rangka penegakan hukum administrasi negara 
ini yaitu peraturan perundang-undangan. Celakanya sampai saat ini peraturan perundangundangan yang ada belum memadai, yang menurut penulis permasalahan tersebut karena : 1.Sempitnya pengertian objek sengketa administrasi negara yang dapat diselesaikan di PTUN. Dengan kata lain, arti ketentuan Pasal 1 angka 3 UU No.5 Tahun 1986 Jo UU No. 9 Tahun 2004 menyimpang dari pengertian sengketa administrasi negara secara luas yang secara teoritis mencakup seluruh perbuatan hukum publik.

2.Hukum administrasi negara formil (hukum acara PTUN) sudah terwujud akan tetapi hukum administrasi negara materiil belum terbentuk.

3.Pelaksanaan eksekusi pengadilan administrasi negara (PTUN) sebagaimana diatur dalam Pasal 116 UU No.5 Tahun 1986 Jo UU No.9 Tahun 2004 belum ditindak lanjuti oleh peraturan pelaksana sehingga tidak ada kejelasan mengenai prosedur dan penerapan hukuman administrasi negaranya.

4.Banyaknya dibentuk lembaga-lembaga peradilan khusus akan tetapi wewenang didalamnya ada yang meliputi penyelesaian sengketa administrasi sehingga menjadi overlap dengan wewenang pengadilan administrasi negara (PTUN), seperti: penyelesaian sengketa perburuhan yang berkaitan dengan keputusan depnakertrans, sengketa HAKI yang bersifat administratif, sengketa pajak, dll.

Permasalahan-permasalahan ini muncul, menurut penulis disebabkan karena tidak adanya harmonisasi dan singkronisasi peraturan perundang-undangan yang ada. Seharusnya sebelum membuat undang-undang para pembentuk undang-undang (DPR dan Pemerintah) membahas dengan cermat dan seksama serta mengikut sertakan para pakar hukum (terutama pakar hukum administrasi negara),apabila perlu disosialisasikan kepada publik (masyarkat/akademisi/LSM) sebelum disahkan untuk menghindari tumpang tindihnya materi muatan antara undang-undang 
satu dengan lainnya.Selain itu untuk efektifitas dan efisiensi penegakkan hukum administrasi negara, tidak perlu dibentuk peradilan-peradilan khusus karena disamping menghamburhamburkan anggaran negara juga menimbulkan ketidakpastian hukum dalam rangka penegakkan hukum. Apabila alasan dibentuknya peradilan khusus hanya karena kurangnya keahlian hakim dalam menyelesaikan perkara tertentu dan lambannya proses berperkara di pengadilan sebetulnya bisa diatasi. Dalam sistem peradilan di Indonesia dimungkinkan keikut sertaan saksi ahli dan hakim ad-hoc karena dibutuhkan disaat lembaga peradilan memerlukankeahliannya untuk menyelesaikan suatu perkara tertentu dan apabila perlu para hakim pengadilan administrasi negara (PTUN) diberi kesempatan studi lanjut untuk mendalami pendidikan khusus (spesialisasi) tentang bidang hukum administrasi negara tertentu (misalnya: Hukum Administrasi Bidang Pajak, Hukum Administrasi Bidang HAKI, Hukum Administrasi Bidang Ketenagakerjaan, dll) sehingga alasan kurangnya keahlian hakim bisa diatasi, sedangkan alasan dibentuknya peradilan khusus dalam rangka mempercepat penyelesaian perkara pun kurang tepat karena dalam praktek justru para pihak yang bersengketa biasanya terlalu lama/ bertele-tele dalam bersidang bahkan ada beberapa pihak yang secara sengaja memperlambat jalannya persidangan dengan maksud-maksud tertentu, sepertiketika pemeriksaan persiapan meskipun dalam undang-undang diatur maksimal perbaikan gugatan dalam tenggang waktu 30 hari, akan tetapi pihak penggugat tidak bisa memperbaiki gugatannnya secepat mungkin. Selain itu, sama halnya dalam persidangan yang terbukauntuk umum dimana para pihak tidak bisa mempersiapkan Jawaban/ Replik/ Duplik/ Alat Buktinya secara cepat dimana dalam prakteknya tiap-tiap acara mereka meminta pengunduran waktu sidang satu. 


\section{BAB III}

\section{PENUTUP}

Dapatlah disimpulkan disini bahwa eksistensi pengadilan administrasi negara (PTUN) adalah selain sebagai salah satu cirri negara hukum modern, juga memberikan perlindungan hukum kepada masyarakat serta aparatur pemerintahan itu sendiri karena pengadilan administrasi negara (PTUN) melakukan kontrol yuridis terhadap perbuatan hukum publik badan atau pejabat administrasi negara. Kaitannya dengan prinsip-prinsip dalam good governancepada dasarnya menjadi pedoman bagi pejabat administrasi negara dalam melaksanakan urusan pemerintahan yaitu mencegah terjadinya KKN (Korupsi, Kolusi, dan Nepotisme), menciptakan birokrasi yang semakin baik, transparan, dan effisien, serta membangun prinsip-prinsip yang lebih demokratis, objektif dan profesional dalam rangka menjalankan roda pemerintahan menuju terciptanya keadilan dan kepastian hukum dalam masyarkat. 


\section{DAFTAR PUSTAKA}

Darmini Roza dan Laurensius Arliman S Peran Pemerintah Daerah Di Dalam Melindungi Hak Anak Di Indonesia, Masalah-Masalah Hukum, Volume 47, Nomor 1, 2018.

Laurensius Arliman S, Komnas HAM dan Perlindungan Anak Pelaku Tindak Pidana, Deepublish, Yogyakarta, 2015.

Laurensius Arliman S, Penguatan Perlindungan Anak Dari Tindakan Human Trafficking Di Daerah Perbatasan Indonesia, Jurnal Selat, Volume 4, Nomor 1, 2016.

Laurensius Arliman S, Problematika Dan Solusi Pemenuhan Perlindungan Hak Anak Sebagai Tersangka Tindak Pidana Di Satlantas Polresta Pariaman, Justicia Islamica, Volume 13, Nomor 2, 2016.

Laurensius Arliman S, Pelaksanaan Perlindungan Anak Yang Tereksploitasi Secara Ekonomi Oleh Pemerintah Kota Padang, Veritas et Justitia, Volume 2, Nomor 1, 2016. 
Laurensius Arliman S, Kedudukan Ketetapan MPR Dalam Hierarki Peraturan PerundangUndangan Di Indonesia, Lex Jurnalica, Volume 13, Nomor 3, 2016.

Laurensius Arliman S, Komnas Perempuan Sebagai State Auxialiary Bodies Dalam Penegakan Ham Perempuan Indonesia, Justicia Islamica, Volume 14, Nomor 2, 2017.

Laurensius Arliman S, Peranan Pers Untuk Mewujudkan Perlindungan Anak Berkelanjutan Di Indonesia, Jurnal Ilmu Hukum Tambun Bungai, Volume 2, Nomor 2, 2017.

Laurensius Arliman S, Mewujudkan Penegakan Hukum Yang Baik Untuk Mewujudkan Indonesia Sebagai Negara Hukum, Jurnal Hukum Doctrinal, Volume 2, Nomor 2, 2017.

Laurensius Arliman S, Participation Non-Governmental Organization In Protecting Child Rights In The Area Of Social Conflict, The 1st Ushuluddin and Islamic Thought International Conference (Usicon), Volume 1, 2017.

Laurensius Arliman S, Partisipasi Masyarakat Dalam Pembentukan Perundang-Undangan Untuk Mewujudkan Negara Kesejahteraan Indonesia, Jurnal Politik Pemerintahan Dharma Praja, Volume 10, Nomor 1, 2017, https://doi.org/10.33701/jppdp.v10i1.379. 
Laurensius Arliman S, Peran Komisi Perlindungan Anak Indonesia Untuk Mewujudkan Perlindungan Anak, Jurnal Respublica Volume 17, Nomor 2, 2018.

Laurensius Arliman S, Menjerat Pelaku Penyuruh Pengrusakan Barang Milik Orang Lain Dengan Mempertimbangkan Asas Fungsi Sosial, Jurnal Gagasan Hukum, Volume 1, Nomor 1, 2019.

Laurensius Arliman S, Ilmu Perundang-Undangan Yang Baik Untuk Negara Indonesia, Deepublish, Yogyakarta, 2019.

Laurensius Arliman S, Isdal Veri, Gustiwarni, Elfitrayenti, Ade Sakurawati, Yasri, Pengaruh Karakteristik Individu, Perlindungan Hak Perempuan Terhadap Kualitas Pelayanan Komnas Perempuan Dengan Kompetensi Sumber Daya Manusia Sebagai Variabel Mediasi, Jurnal Menara Ekonomi: Penelitian dan Kajian Ilmiah Bidang Ekonomi, Volume 6, Nomor 2, 2020.

Laurensius Arliman S, Pendidikan Kewarganegaraan, Deepublish, Yogyakarta, 2020. 
Laurensius Arliman S, Makna Keuangan Negara Dalam Pasal Pasal 23 E Undang-Undang Dasar 1945, Jurnal Lex Librum, Volume 6, Nomor 2 Juni 2020, http://dx.doi.org/10.46839/1ljih.v6i2.151.

Laurensius Arliman S, Kedudukan Lembaga Negara Independen Di Indonesia Untuk Mencapai Tujuan Negara Hukum, Kertha Semaya Journal Ilmu Hukum, Volume 8, Nomor 7, 2020.

Laurensius Arliman S, Pelaksanaan Assesment Oleh Polres Kepulauan Mentawai Sebagai Bentuk Pelaksanaan Rehabilitasi Bagi Pecandu Dan Korban Penyalahgunaan Narkotika, Jurnal Muhakkamah, Volume 5, Nomor 1, 2020.

Laurensius Arliman S, Aswandi Aswandi, Firgi Nurdiansyah, Laxmy Defilah, Nova Sari Yudistia, Ni Putu Eka, Viona Putri, Zakia Zakia, Ernita Arief, Prinsip, Mekanisme Dan Bentuk Pelayanan Informasi Kepada Publik Oleh Direktorat Jenderal Pajak, Volume 17, No Nomor, 2020.

Larensius Arliman S, Koordinasi PT. Pegadaian (Persero) Dengan Direktorat Reserse Narkoba Polda Sumbar Dalam Penimbangan Barang Bukti Penyalahgunaan Narkotika, UIR Law Review, Volume 4, Nomor 2, 2020, https://doi.org/10.25299/uirlrev.2020.vol4(1).3779. 
Laurensius Arliman S, Tantangan Pendidikan Kewarganegaraan Pada Revolusi 4.0, Ensiklopedia Sosial Review, Volume 2, Nomor 3, 2020.

Muhammad Afif dan Laurensius Arliman S, Protection Of Children's Rights Of The Islamic And Constitutional Law Perspective Of The Republic Of Indonesia, Proceeding: Internasional Conference On Humanity, Law And Sharia (Ichlash), Volume 1, Nomor 2, 2020.

Otong Rosadi danLaurensius Arliman S, Urgensi Pengaturan Badan Pembinaan Idelogi Pancasila Berdasarkan Undang-Undang Sebagai State Auxiliary Bodies yang Merawat Pancasila dalam Perspektif Hak Asasi Manusia, Prosiding Konferensi Nasional Hak Asasi Manusia, Kebudayaan dan Tujuan Pembangunan Berkelanjutan Indonesia pada Masa Pandemi Covid-19: Tantangan untuk Keilmuan Hukum dan Sosial Volume 1, Universitas Pancasila, Jakarta, 2020. 